\title{
Dejavniki akademskega odlašanja: vloga perfekcionizma, anksioznosti in depresivnosti
}

\author{
Eva Kranjec ${ }^{*}$, Katja Košir ${ }^{2}$ in Luka Komidar ${ }^{3}$ \\ ${ }^{1}$ Križevci pri Ljutomeru \\ ${ }^{2}$ Oddelek za temeljne pedagoške predmete, Pedagoška fakulteta, Univerza v Mariboru \\ ${ }^{3}$ Oddelek za psihologijo, Filozofska fakulteta, Univerza v Ljubljani
}

\begin{abstract}
Povzetek: V raziskavi smo preučevali dimenzije perfekcionizma, anksioznosti in depresivnosti kot dejavnike, ki se povezujejo z odlašanjem $\mathrm{z}$ akademskim delom. Osrednji namen raziskave je bil preveriti moderatorsko vlogo dimenzij perfekcionizma $\mathrm{v}$ odnosu med stopnjo anksioznosti in depresivnosti ter akademskim odlašanjem. Na vzorcu 403 študentov smo uporabili štiri lestvice: lestvico perfekcionizma FMPS, lestvico akademske prokrastinacije APS-SI, lestvico depresivnosti CESD in lestvico anksioznosti STAIX2. Rezultati so pokazali, da na slovenskem vzorcu študentov obstaja statistično značilen pozitiven odnos med neprilagojenimi dimenzijami perfekcionizma, anksioznostjo, depresivnostjo in akademskim odlašanjem. Obenem so rezultati pokazali pomembno negativno povezanost med prilagojenima dimenzijama perfekcionizma in akademskim odlašanjem. Prav tako se je izkazalo, da so določene dimenzije perfekcionizma, anksioznost in depresivnost pomembni napovedniki akademskega odlašanja. Nadalje je analiza rezultatov pokazala, da odnos med stopnjo anksioznosti in akademskim odlašanjem moderira le ena od šestih dimenzij perfekcionizma (dimenzija osebni standardi), medtem ko odnos med stopnjo depresivnosti in akademskim odlašanjem moderira neprilagojena dimenzija pričakovanja staršev.
\end{abstract}

Ključne besede: akademsko odlašanje, perfekcionizem, anksioznost, depresivnost, študenti

\section{Factors of academic procrastination: The role of perfectionism, anxiety and depression}

\author{
Eva Kranjec ${ }^{1 *}$, Katja Košir ${ }^{2}$ and Luka Komidar ${ }^{3}$ \\ ${ }^{1}$ Križevci pri Ljutomeru, Slovenia \\ ${ }^{2}$ Department of Basic Pedagogical Studies, Faculty of Education, University of Maribor, Slovenia \\ ${ }^{3}$ Department of Psychology, Faculty of Arts, University of Ljubljana, Slovenia
}

\begin{abstract}
This study investigated dimensions of perfectionism, anxiety, and depression as factors of academic procrastination. Our main research interest was to examine the role of specific dimensions of perfectionism as moderators in the relationship between anxiety and depression and academic procrastination. Four scales were administered on the sample of 403 students: perfectionism scale FMPS, academic procrastination scale APS-SI, depression scale CESD and anxiety scale STAI-X2. The results showed significant positive relationships between maladaptive dimensions of perfectionism, anxiety, depression, and academic procrastination. In addition, results showed significant negative associations between adaptive dimensions of perfectionism and academic procrastination. Certain dimensions of perfectionism, anxiety, and depression proved to be significant predictors of academic procrastination. The dimensions of perfectionism and academic procrastination were also significantly related to anxiety and depression, which both predicted academic procrastination. The relationship between anxiety levels and academic procrastination was moderated by personal standards (as adaptive dimension of perfectionism), while the relationship between depression levels and academic procrastination was moderated by the maladaptive dimension of parents' expectations.
\end{abstract}

Keywords: academic procrastination, perfectionism, anxiety, depression, students

\footnotetext{
*Naslov/Address: Eva Kranjec, Križevci 2A, 9242 Križevci pri Ljutomeru, e-pošta: kranjec.eva@gmail.com
} 
Pojav odlašanja (angl. procrastination), ki ga v najširšem smislu opredeljujemo kot posameznikovo težnjo k odložitvi ali izogibanju nalog, je izjemno pogost; v določeni meri ga lahko zasledimo pri vsakem posamezniku na različnih področjih življenja (McCloskey, 2011). Splošno odlašanje ni le izid neustreznih delovnih navad ali slabe organizacije časa, temveč je pojav, ki sestoji iz vrste vedenjskih, kognitivnih in čustvenih komponent, kot so strah pred neuspehom, anksioznost, težnja k popolnosti, nizka stopnja samopodobe in averzivne naloge (Solomon in Rothblum, 1984). Izvori in vzdrževalni dejavniki tega pojava so različni. Pogosto omenjen dejavnik odlašanja je perfekcionizem, pri čemer se še posebej oblika odlašanja $\mathrm{z}$ akademskim delom obravnava kot možen izid posameznikovih teženj k popolnosti (Frost, Marten, Lahart in Rosenblate, 1990). Čeprav se pojav odlašanja pozitivno povezuje s perfekcionizmom, anksioznostjo in depresivnostjo (npr. Frost idr., 1990; Haycock, McCarthy in Skay, 1998; Saddler in Sacks, 1993), ostaja narava njihovih medsebojnih odnosov dokaj nejasna. Cilj pričujoče raziskaveje na slovenskem vzorcu študentov preveriti, kakšne so povezave med omenjenimi konstrukti, pri čemer nas je zanimalo, ali so konstrukti perfekcionizma, anksioznosti in depresivnosti pomembni napovedniki akademskega odlašanja. Osrednji interes raziskave je bil usmerjen $\mathrm{v}$ preverjanje moderatorske vloge dimenzij perfekcionizma $\mathrm{v}$ odnosu med stopnjo anksioznosti in depresivnosti ter akademskim odlašanjem.

\section{Akademsko odlašanje}

Odlašanje z akademskim delom je izjemno pogost pojav, saj se po ugotovitvah nekaterih raziskav pojavlja pri več kot $70 \%$ študentov (McCloskey, 2011; Schraw, Wadkins in Olafson, 2007). Opredeljujemo ga kot vedenje učenca, ki namerno in nepotrebno odlaša ali prelaga šolske obveznosti. Odlašanje $\mathrm{z}$ delom do postavljenega roka lahko pri posamezniku povzroči doživljanje stresa in anksioznosti, vpliva na psihično blagostanje ter njegove odnose $\mathrm{z}$ drugimi (McCloskey, 2011). Odlašanje $\mathrm{z}$ akademskim delom je $\mathrm{v}$ večji meri značilno za učence s povišano stopnjo strahu pred negativnim ocenjevanjem s strani drugih, za učence z nizkimi osebnimi standardi glede lastnih dosežkov in učence, ki se ne vključujejo v učne aktivnosti zaradi dosežkov ali ocen (Saddler in Buley, 1999). Izvori odlašanja $z$ akademskim delom segajo $\mathrm{v}$ obdobje zgodnjega šolanja, ko posameznik prične oblikovati predstavo o lastnih sposobnostih. Pogosto se zgodi, da posamezniki z odlašajočim vedenjem prikrivajo svoja šibka področja (Burka in Yuen, 2008).

$\mathrm{K}$ odlašajočemu vedenju pomembno prispeva posameznikova prepričanost o boljšem opravljanju dela pod časovnim pritiskom, saj naj bi slednji pomembno vplival na dvig stopnje učinkovitosti. Nadalje je za pojav odlašajočega vedenja pomembna stopnja pozornosti, ki je pri posameznikih z višjo stopnjo akademskega odlašanja pogosto usmerjena na druge (zanimivejše) aktivnosti (McCloskey, 2011). V povezavi s tem se neredko pojavijo tudi učna samooviralna vedenja (Steel, 2007). K omenjenemu pojavu prispevajo tudi neustrezno organiziran čas za šolske obveznosti, odsotnost notranje motivacije za pričetek delovne aktivnosti, občutki zdolgočasenosti in pomanjkanje splošne motivacije kljub fizični pripravljenosti (McCloskey, 2011; Schraw idr., 2007).
Pomemben vidik predstavljajo tudi družbeni dejavniki, ki pridejo do izraza $\mathrm{v}$ obdobju pozne adolescence in zgodnje odraslosti, ko je $\mathrm{v}$ ospredju posameznikova težnja $\mathrm{k}$ neodvisnosti ter družbenemu prilagajanju. Posameznik v teh obdobjih usklajuje več stvari hkrati - čas za študijske obveznosti, delo, družino in prijatelje. Zaradi težnje k neodvisnosti in avtonomiji pogosto posveti več časa delu in druženju z vrstniki, zaradi česar prihaja do odlašanja $\mathrm{z}$ akademskim delom (Schraw idr., 2007).

Pojav odlašanja $z$ akademskimi obveznostmi se v vedenju kaže $\mathrm{v}$ treh oblikah: pomanjkanju točnosti $\mathrm{v}$ namenu in vedenju, neskladnosti med namenom in vedenjem ter $\mathrm{v}$ izvedbi drugih (posamezniku zanimivejših) aktivnostih. Pomembni mehanizmi, ki so $\mathrm{v}$ ozadju pojava odlašanja $\mathrm{z}$ akademskim delom in ga do določene mere vzdržujejo, so strah pred neuspehom, iracionalna prepričanja in negativna samopodoba (Schouwenburg, 1995). Strah pred neuspehom sproža izogibajoča vedenja, na podlagi česar lahko odlašanje z akademskim delom obravnavamo kot eno od strategij spoprijemanja (Burka in Yuen, 2008; Schouwenburg, 1995). Iz strahu pred neuspehom izhajajo iracionalna prepričanja, ki so v luči odlašajočega vedenja samokritična in katastrofalna ter odvračajo posameznika od dokončanja naloge (Burka in Yuen, 2008). Pri posameznikih z visoko stopnjo odlašanja $\mathrm{z}$ akademskim delom lahko zaznamo obrambna vedenja, vezana na njihove pomanjkljivosti, še posebej v situacijah javnega ocenjevanja. Zaznana defenzivnost izhaja iz znižanega občutka lastne vrednosti, ki je pomemben vidik posameznikove samopodobe (Ferrari, 1992).

Čeprav nekateri avtorji (npr. Choi in Moran, 2009; Chu in Choi, 2005) obravnavajo odlašanje $z$ akademskim delom kot pozitiven pojav, ima $\mathrm{v}$ večji meri vrsto notranjih in zunanjih negativnih posledic. Kot posledica nezadovoljstva z nezmožnostjo opraviti zadano delo se pri posameznikih $\mathrm{z}$ višjo stopnjo odlašanja $\mathrm{z}$ akademskimi obveznostmi izkažejo različne frustracije in jeza. Posamezniki pogosto doživljajo krivdo, obžalovanje, obup, so razdražljivi in se nagibajo k samoobsojanju. Slabša se akademska in delovna produktivnost, izgubijo se pomembne priložnosti, medosebni odnosi lahko postanejo napeti (Burka in Yuen, 2008).

\section{Odnos med akademskim odlašanjem in perfekcionizmom}

Zgodnje konceptualizacije so perfekcionizem prikazovale kot enodimenzionalen in izjemno patološki konstrukt (Ganske in Ashby, 2007). Opredeljen je bil kot negativna osebnostna poteza, ki se nanaša na neutemeljene zahteve posameznika do sebe ali drugih, pri čemer kakovost predstave o tem presega tisto, kar se zahteva $\mathrm{v}$ dani situaciji (Hollender, 1965). Zgodnjim pojmovanjem so $\mathrm{v}$ nadaljnjih letih raziskovalci priključili socialno dimenzijo, zaradi česar danes obravnavamo perfekcionizem kot večdimenzionalen konstrukt, ki vključuje tako prilagojene (angl. adaptive) kot neprilagojene (angl. maladaptive) dimenzije (Frost idr., 1990; Hewitt in Flett, 1991; Slade in Owens, 1998).

Modelov, ki ustrezno pojasnjujejo večdimenzionalnost omenjenega konstrukta, je več. Po modelu Frosta in sodelavcev (1990) perfekcionizem vključuje šest dimenzij. Štiri so usmerjene na posameznika (osebni standardi, dvom v dejanja, 
zaskrbljenost zaradi napak in organiziranost) ter se nanašajo na postavitev visokih standardov glede lastne predstave, posameznikove dvome $\mathrm{v}$ sposobnosti glede opravljanja naloge, težnjo k negativnemu odzivanju na napake in enačenju napak z neuspehom ter posameznikovo držo do urejenosti in reda. Preostali dve dimenziji (pričakovanja staršev in starševska kritika) odražata vpliv pomembnih drugih na posameznika ter se nanašata na posameznikova prepričanja o strogosti staršev in postavljanju previsokih standardov (Flett in Hewitt, 2002). Iz tega modela sta nadalje izhajala avtorja Hewitt in Flett (1991), ki sta perfekcionizem opredelila kot konstrukt s tremi dimenzijami. Dimenzija »nase usmerjeni perfekcionizem« zajema na posameznika usmerjena perfekcionistična vedenja, ki se odražajo $\mathrm{v}$ postavljanju visokih standardov, strogem ocenjevanju lastnega vedenja, samokritičnosti, samokaznovanju, prizadevanju za doseganje popolnosti $\mathrm{v}$ izvedenih dejanjih in izogibanje napakam. Dimenzija »na druge usmerjeni perfekcionizem« odraža navzven usmerjene perfekcionistične težnje posameznika. Dimenzija »družbeno predpisani perfekcionizem《 se nanaša na doseganje standardov in pričakovanj, predpisanih s strani družbe, za katero posameznik meni, da od njega pričakuje popolnost.

Frost, Heimberg, Holt, Mattia in Neubauer (1993) so predstavljena modela primerjali ter ugotovili, da so posamezne dimenzije med seboj primerljive in skladne. Na tej osnovi so opredelili dve skupini dimenzij, in sicer prilagojene (angl. adaptive) in neprilagojene (angl. maladaptive) dimenzije perfekcionizma. K prilagojenim prištevamo organiziranost, osebne standarde, $\mathrm{k}$ sebi usmerjen perfekcionizem in na druge usmerjen perfekcionizem. V skupino neprilagojenih dimenzij perfekcionizma prištevamo zaskrbljenost zaradi napak, dvom v dejanja, pričakovanja staršev, starševsko kritiko in družbeno predpisan perfekcionizem. V pričujoči raziskavi smo izhajali le iz šestdimenzionalnega modela perfekcionizma Frosta in sodelavcev (1990), pri čemer smo posamezne dimenzije glede na kasnejšo delitev Frosta in sodelavcev (1993) opredelili kot prilagojene ali neprilagojene. Slednje namreč omogoča enostavnejše spremljanje in razumevanje omenjenih dimenzij.

Čeprav je perfekcionizem v prilagojenih oblikah lahko koristen, saj posameznika motivira, da doseže svoje cilje, se v večji meri povezuje s številnimi neugodnimi izidi. Vodi lahko do enostavnejših motenj, ki niso nujno patološke narave, temveč izražajo le določeno mero simptomatike. Pogosto izpostavljena je pozitivna povezava neprilagojenih oblik perfekcionizma s (socialno) anksioznostjo (Frost idr., 1990; Kawamura, Hunt, Frost in DiBartolo, 2001) in depresivnostjo (Erozkan, Karakas, Atak in Ayberg, 2011; Frost idr., 1990; Zhang in Cai, 2012).

Tako perfekcionizem kot odlašanje $\mathrm{z}$ akademskimi obveznostmi se povezujeta s strahom pred neuspehom, ki vključuje pojav posameznikove anksioznosti $\mathrm{v}$ zvezi $\mathrm{z}$ ocenjevanjem, postavitev previsokih standardov glede izvedbe naloge in nižjo stopnjo samopodobe. Učenci tako odlašajo z akademskimi obveznostmi zaradi nezmožnosti doseganja lastnih pričakovanj ali pričakovanj drugih in skrbi za slabo izvedene študijske obveznosti (Burka in Yuen, 2008; Flett, Blankstein, Hewitt in Koledin, 1992; Frost idr., 1990; Solomon in Rothblum, 1984). Slednje podpira pozitivna povezava med neprilagojenimi dimenzijami perfekcionizma (npr. zaskrbljenost zaradi napak in dvom $\mathrm{v}$ dejanja) in odlašanjem $\mathrm{z}$ akademskimi obveznostmi, pri čemer omenjena povezava nakazuje na nefunkcionalnost odnosa med omenjenimi spremenljivkami (Frost idr., 1990; Jadidi, Mohammadkhani in Tajrishi, 2011). Perfekcionizem se je tudi izkazal kot pomemben napovednik akademskega odlašanja (Burnam, Komarraju, Hamel in Nadler, 2014), pri čemer vedenja posameznikov z višjo stopnjo akademskega odlašanja pogosto spremlja socialna anksioznost (Ferrari, 1992).

\section{Odnos med akademskim odlašanjem in anksioznostjo}

Anksioznost opredeljujemo kot trenutno stanje ali osebnostno potezo. $\mathrm{V}$ tem prispevku anksioznost opredeljujejmo kot osebnostno potezo; opredeljena je kot splošna predispozicija osebe in relativna stabilna nagnjenost k zaznavanju situacij kot ogrožujočih, na katere posameznik odreagira $\mathrm{Z}$ različno stopnjo anksioznosti (Spielberger, 1985, v Lamovec, 1988). Anksioznost se pogosto pojavi kot izid strahu pred neuspehom, zaradi česar se povezuje tako s perfekcionizmom in njegovimi neprilagojeni dimenzijami kot $\mathrm{z}$ odlašanjem na akademskem področju (Haycock idr., 1998; Kawamura idr., 2001; Solomon in Rothblum, 1984). Chang (2012) je anksioznost potrdil tudi kot izjemno močan napovednik akademskega odlašanja, pri čemer naj bi anksioznost zavzemala mediatorsko vlogo v odnosu med neprilagojenimi dimenzijami perfekcionizma in odlašanjem na akademskem področju ter moderatorsko vlogo med prilagojenimi dimenzijami perfekcionizma in odlašanjem na akademskem področju. Posamezniki z močneje izraženimi neprilagojenimi perfekcionističnimi težnjami težijo $\mathrm{k}$ doseganju kriterijev drugih, pri čemer doživljajo anksioznost in se nagibajo $\mathrm{k}$ odlašajočemu vedenju. Povezava med stopnjo anksioznosti in akademskim odlašanjem je nižja (ali celo negativna) za posameznike $\mathrm{z}$ močneje izraženimi prilagojenimi dimenzijami perfekcionizma (Chang, 2012).

\section{Odnos med akademskim odlašanjem in depresivnostjo}

Pri opredelitvi depresivnosti je potrebno ločevati med izrazoma depresivnost in klinična depresija. V tem prispevku obravnavamo depresivnost, ki se v splošnem nanaša na običajno občutenje žalosti oziroma depresivnega razpoloženja. Označujejo jo anhedonija, neodločnost, brezvoljnost in izguba interesov. Mišljenje postane zavrto, pogosto se pojavita tudi odvisnost od drugih in samokritika. Kadar se prisotnost naštetih simptomov poveča in če ti pričnejo onemogočati posameznikovo vsakdanje funkcioniranje, lahko govorimo o klinični depresiji. Klinična depresija spada v spekter čustvenih in razpoloženjskih motenj, zraven zgoraj naštetih značilnosti pa jo odražajo tudi značilnosti znižanega razpoloženja in ravni energije, izgube zadovoljstva, zmanjšane pozornosti, mislih o samopoškodbenemu vedenju in občutkov krivde 
(Antony in Swinson, 2009). Perfekcionistični posamezniki so, tako kot $\mathrm{k}$ anksiznosti, nagnjeni tudi k razvoju depresivnih simptomov; perfekcionizem se je izkazal kot pomemben napovednik depresivnosti (Zhang in Cai, 2012). Negativne avtomatske misli in neustrezna prepričanja imajo kot pomembni vidiki depresivnosti pomembno vlogo pri razvoju vedenjskih vzorcev odlašanja $\mathrm{z}$ akademskih delom (Flett, Blankstein in Martin, 1995). Z ozirom na pozitivno povezavo med omenjenima konstruktoma raziskovalci sklepajo, da posamezniki z negativnimi prepričanji o svoji kognitivni učinkovitosti v večji meri dvomijo v lastne sposobnosti, kar vpliva na stopnjo motivacije za pričetek ukvarjanja $\mathrm{z}$ delovno nalogo in vodi v vedenjske vzorce izogibanja ter prelaganja $\mathrm{z}$ akademskim delom (Spada, Hiou in Nikcevic, 2006).

\section{Namen in cilji raziskave}

Narava odnosa med konstrukti akademskega odlašanja, perfekcionizma, anksioznosti in depresivnosti je še vedno precej neraziskano področje. Namen prispevka je izboljšanje prepoznavnosti problematike odlašanja na akademskem področju, pri čemer je na podlagi pridobljenih spoznanj možno utemeljiti zlasti pedagoške ukrepe. Cilj pričujoče raziskave je preučiti odnose med zgoraj navedenimi konstrukti na slovenskem vzorcu študentov. Preveriti smo želeli, v kakšni smeri se posamezne dimenzije perfekcionizma, anksioznost in depresivnost povezujejo $\mathrm{s}$ konstruktom odlašanja $\mathrm{z}$ akademskim delom. Nadalje smo želeli preučiti, ali se na slovenskem vzorcu udeležencev spremenljivke neprilagojene dimenzije perfekcionizma, anksioznost in depresivnost izkažejo kot pomembni pozitivni napovedniki odlašanja $\mathrm{z}$ akademskim delom ter ali se prilagojene dimenzije perfekcionizma izkažejo kot negativni napovedniki akademskega odlašanja. Pričakovali smo, da se bodo neprilagojene dimenzije perfekcionizma, anksioznost in depresivnost pozitivno povezovale $\mathrm{Z}$ akademskim odlašanjem, medtem ko se bosta prilagojeni obliki perfekcionizma negativno povezovali z akademskim odlašanjem. Prej navedeni raziskovalni izsledki opredeljujejo perfekcionizem, anksioznost in depresivnost kot korelate ter možne predhodnike akademskega odlašanja. Zaradi tega je predstavljal osrednji cilj raziskave preverjanje moderatorske vloge posameznih dimenzij perfekcionizma $\mathrm{v}$ odnosu med stopnjo anksioznosti in stopnjo odlašanja z akademskim delom ter v odnosu med stopnjo depresivnosti in stopnjo odlašanja $\mathrm{z}$ akademskim delom, kar omogoča boljše razumevanje narave odnosa med obravnavanimi spremenljivkami. V tem sklopu raziskave smo pričakovali, da bodo neprilagojene oblike perfekcionizma moderirale odnos med anksioznostjo in akademskim odlašanjem tako, da bo v pogoju visoke stopnje neprilagojenih oblik perfekcionizma povezava med njima višja. Nadalje smo pričakovali, da bosta prilagojeni dimenziji perfekcionizma moderirali odnos med anksioznostjo in akademskim odlašanjem tako, da bo v pogoju visoke stopnje prilagojenih oblik perfekcionizma povezava med njima nižja. Ista pričakovanja smo zastavili za preverjanje moderatorske vloge dimenzij perfekcionizma $\mathrm{v}$ odnosu med stopnjo depresivnosti in akademskim odlašanjem.

\section{Metoda}

\section{Udeleženci}

$\mathrm{V}$ raziskavi so sodelovali 403 študentje, od tega 126 moških $(31,3 \%)$ in 277 žensk $(68,7 \%)$. Povprečna starost udeležencev je bila 21,2 let $(S D=2,3 ; \min =19, \max =40)$. Udeleženci so bili študentje prve in druge bolonjske stopnje družboslovnih, humanističnih ter tehničnih študijskih smeri. Vzorčenje je bilo priložnostno.

\section{Pripomočki}

Noben od uporabljenih instrumentov še ni bil ustrezno prirejen za slovensko kulturno in jezikovno okolje (opravljeni so bili le prevodi postavk). Zaradi tega smo $\mathrm{z}$ uporabo konfirmatorne faktorske analize preverili konstruktno veljavnost Frostove lestvice perfekcionizma, Lestvice depresivnosti CESD in Lestvice anskioznosti STAI-X2. Vse analize so bile opravljene v programu Mplus 7 (Muthén in Muthén, 1998-2010) z uporabo WLSMV (angl. Meanand Variance-adjusted Weighted Least Squares) cenilke parametrov, ki je v Mplusu privzeta cenilka za ordinalne podatke (in podatke, katerih porazdelitev se ne prilega normalni porazdelitvi). Pri odločanju o ustreznosti prileganja modelov smo uporabili naslednje mere: $\chi^{2}$, RMSEA (angl. Root Mean Square Error of Approximation), CFI (angl. Comparative Fit Index) in TLI (angl. Tucker Lewis Index). Za določanje ustreznosti prileganja modelov smo uporabili sledeče mejne vrednosti: RMSEA $<0,08 ;$ CFI $>$ (ali blizu) 0,90; TLI > (ali blizu) 0,90.

Lestvica akademske prokrastinacije (APS SI; Academic Procrastination Scale). Lestvico APS SI (McCloskey, 2011) sestavlja 25 trditev, ki se nanašajo na posameznikove študijske navade in rutine (primer: Zalotil sem se, da sem z delom za večji projekt začel dan pred začetkom projekta). Posameznik vrednoti vseh 25 postavk na petstopenjski ocenjevalni lestvici ( 1 - sploh se ne strinjam; 5 - močno se strinjam). Končni rezultat se izračuna kot seštevek ocen pri vseh podanih postavkah. Lestvico so na Oddelku za psihologijo Filozofske fakultete Univerze v Ljubljani V slovenski jezik prevedli Sever, Senegačnik in Vajngerl (2015). Alfa koeficient zanesljivosti izvorne lestvice je visok - 0,95 (McCloskey, 2011). Pilotna raziskava je pokazala tudi visok koeficient zanesljivosti na slovenskem vzorcu $(0,92)$ ter enodimenzionalno strukturo instrumenta (Sever, Senegačnik in Vajngerl, 2015). Koeficient zanesljivosti, pridobljen na naših podatkih, znaša 0,93 .

Frostova lestvica perfekcionizma (Frost Multidimensional Perfectionism Scale). Frostova lestvica perfeksionizma (Frost idr., 1990) je sestavljena iz 35 postavk, s katerimi preverjamo perfekcionistične težnje posameznikov na šestih dimenzijah. Dimenzije, ki so vključene v lestvico, so naslednje: zaskrbljenost zaradi napak (primer: Če mi spodleti pri delu oziroma v šoli, se počutim kot zguba.), osebni standardi (primer: Če si ne bom postavljal/-a najvišjih zahtev, bom verjetno končal/-a kot drugorazredna oseba.), pričakovanja staršev (primer: Starši so mi postavljali zelo 
visoke zahteve.), starševska kritika (primer: Kot otrok sem bil/-a kaznovan/-a, če česa nisem naredil/-a popolno.), dvom v dejanja (primer: Tudi kadar kaj posebej skrbno naredim, imam občutek, da ni povsem $\mathrm{v}$ redu.) in organiziranost (primer: Trudim se biti organizirana oseba.). Udeleženci vrednotijo vseh 35 postavk na 5-stopenjski ocenjevalni lestvici $(1$ - sploh ne drži; 5 - povsem drži). Vse postavke vrednotimo pozitivno. Končni rezultat je seštevek ocen na posameznih dimenzijah. Slovenska priredba je bila pod vodstvom dr. Boštjana Bajca pripravljena na osnovi dvojnega prevoda $v$ slovenščino in vzvratnega prevoda.

$\mathrm{Z}$ uporabo konfirmatorne faktorske analize smo preverili konstruktno veljavnost lestvice na slovenskih podatkih. V modelu smo ocenjevali tudi korelacije med faktorji. Prileganje 6-faktorskega modela je bilo zadovoljivo, $\chi^{2}(545)=1589,1$; RMSEA $=0,069 ;$ CFI $=0,90 ;$ TLI $=0,89$. Standardizirane faktorske nasičenosti so bile v povprečju visoke: zaskrbljenost zaradi napak, $M(\lambda)=0,71$; dvom $\mathrm{v}$ dejanja, $M(\lambda)=0,60$; osebni standardi, $M(\lambda)=0,67$; pričakovanja staršev, $M(\lambda)=$ 0,74 ; starševska kritika $M(\lambda)=0,74$ in organiziranost, $M(\lambda)$ $=0,82$.

Alfa koeficienti zanesljivosti posameznih dimenzij izvorne lestvice so zadovoljivi: zaskrbljenost zaradi napak 0,88 ; osebni standardi 0,83 ; pričakovanja staršev 0,84 ; starševska kritika 0,84; dvom v dejanja 0,77; organiziranost 0,93 (Frost idr., 1990). Podobne velikosti koeficientov zanesljivosti smo dobili tudi na našem vzorcu: zaskrbljenost zaradi napak 0,86 ; osebni standardi 0,82 ; pričakovanja staršev 0,80 ; starševska kritika 0,72 ; dvom v dejanja 0,65 ; organiziranost 0,87 .

Lestvica depresivnosti (CESD; The Center for Epidemologic Studies Depression Scale). Lestvica CESD (Radloff, 1977; v Carleton idr., 2013) v originalu sestoji iz 20 postavk, vendar so na osnovi kasnejših raziskav predlagali uporabo le 14 postavk, ki so vključene v tri faktorje: negativni afekt (primer: Počutil/-a sem se depresivno.), anhedonija (primer: Bil/-a sem zadovoljen/-na) in somatski simptomi (primer: Nisem imel/-a apetita.). Z omenjeno lestvico merimo stopnjo depresivne simptomatike pri normalni populaciji, poudarja predvsem čustveno komponento in ni namenjena diagnosticiranju resnosti bolezni. Udeleženci na 4-stopenjski ocenjevalni lestvici ( 1 - redko; 4 - večinoma) odgovarjajo na postavke, ki se nanašajo na pogostost določenih občutij v zadnjem tednu. Končni rezultat predstavlja seštevek odgovorov na posamezne trditve.

Pri preverjanju konstruktne veljavnosti lestvice smo ocenjevali tudi korelacije med faktorji. Prileganje 3faktorskega modela je bilo ustrezno, $\chi^{2}(74)=225,6$; RMSEA $=0,071 ; \mathrm{CFI}=0,96$; TLI $=0,95$. Standardizirane faktorske nasičenosti so bile v povprečju visoke: negativni afekt, $M(\lambda)$ $=0,77$; somatski simptomi, $M(\lambda)=0,62$; anhedonija $M(\lambda)=$ 0,67 . Preverili smo tudi prileganje faktorskega modela drugega reda, v katerem (trije) faktorji prvega reda predstavljajo indikatorje splošnega faktorja drugega reda. Tudi ta model se je zadovoljivo prilegal podatkom, $\chi^{2}(74)=194,3$; RMSEA $=$ 0,064; CFI =0,92; TLI =0,90.

Alfa koeficienti zanesljivosti izvorne lestvice se gibljejo med 0,87 in 0,92 . Koeficient zanesljivosti celotne lestvice se je na našem vzorcu izkazal kot zadovoljiv $(0,86)$.
Lestvica anksioznosti STAI-X2 (State Trait Anxiety Inventory - X2). STAI-X2 (Spielberger, Gorsuch in Lushen, 1977, v Lamovec, 1988) meri anksioznost kot potezo in se nanaša na posameznikovo splošno predispozicijo za zaznavanje ogrožajočih situacij in odzivanje nanje z določeno mero tesnobnosti. Sestavlja jo 20 trditev, s katerimi ljudje opisujejo sami sebe (primer: Preveč me skrbijo stvari, ki niso resnično pomembne) in na katere posameznik odgovarja na 4-stopenjski lestvici (1 - nikakor; 4 -zelo). Končni rezultat predstavlja seštevek odgovorov na vse trditve.

Prileganje enofaktorskega modela je bilo zadovoljivo, $\chi^{2}(170)=628,4 ;$ RMSEA $=0,082 ;$ CFI $=0,93 ;$ TLI $=0,92$. Standardizirane faktorske nasičenosti so v povprečju znašale 0,63. Musek in Avsec (2006) poročata o zadovoljivem koeficientu notranje konsistentnosti $(0,88)$. Koeficient zanesljivosti na našem vzorcu je bil prav tako ustrezen $(0,90)$.

\section{Postopek}

Priprave na izvedbo anketiranja udeležencev so potekale februarja 2015. Apliciranje vprašalnikov je bilo izvedeno konec februarja in v začetku marca 2015. Meritve so potekale $\mathrm{v}$ predavalnicah na začetku ali proti koncu predavanj ali vaj. Udeleženci so vprašalnike izpolnjevali prostovoljno in $\mathrm{v}$ obliki papir-svinčnik. Izpolnjevanje vprašalnikov je potekalo približno petnajst minut. Udeležencem je bila zagotovljena anonimnost.

\section{Statistične analize}

V kolikšni meri dimenzije perfekcionizma napovedujejo akademsko odlašanje in moderirajo odnos med stopnjo anksioznosti in depresivnosti ter akademskim odlašanjem, smo preverili s hierarhično multiplo regresijo, pri čemer smo za vse nadaljnje analize uporabili metodo vključitve (angl. Enter). Za dovolj ustrezen prikaz izbranih analiz smo oblikovali dva modela, ki se med seboj razlikujeta v nekaterih napovednikih, in sicer smo izvedli ločeni regresijski analizi $\mathrm{z}$ anksioznostjo in depresivnostjo kot napovednikoma. Za lažjo interpretacijo učinkov prediktorjev (spol, starost, dimenzije perfekcionizma, anksioznost in depresivnost) in njihovih produktov na kriteriju (akademsko odlašanje) smo spremenljivke pred začetkom analize centrirali. Predpostavkam za izvedbo regresijske analize je bilo zadoščeno. Za boljšo predstavljivost rezultatov hierarhične multiple regresije smo odnose med interakcijskimi spremenljivkami in odvisno spremenljivko prikazali $\mathrm{z}$ grafičnimi prikazi, pri čemer smo pri delitvi interakcijskih spremenljivk v skupine sledili priporočilom avtorjev Aiken in West (1991); nizka stopnja predstavlja povprečno vrednost spremenljivke minus en standardni odklona, visoka stopnja pa predstavlja povprečno vrednost spremenljivke plus en standardni odklon. 
Tabela 1. Mere opisne statistike in Pearsonovi koeficienti korelacij med obravnavanimi spremenljivkami

\begin{tabular}{|c|c|c|c|c|c|c|c|c|c|c|c|c|c|}
\hline & $M$ & $S D$ & 1 & 2 & 3 & 4 & 5 & 6 & 7 & 8 & 9 & 10 & 11 \\
\hline Starost & 21,16 & 2,31 & & & & & & & & & & & \\
\hline 1. Akademsko odlašanje & 64,93 & 17,31 & & & & & & & & & & & \\
\hline 2. $\mathrm{P}$ - zaskrbljenost zaradi napak & 20,00 & 6,46 &, $17^{* *}$ & & & & & & & & & & \\
\hline 3. $\mathrm{P}$ - osebni standardi & 21,36 & 5,16 &, $16^{* *}$ &, $47^{* *}$ & & & & & & & & & \\
\hline 4. $\mathrm{P}$ - starševska kritika & 7,14 & 2,90 & $23^{* *}$ &, $42^{* *}$ &, $13^{* *}$ & & & & & & & & \\
\hline 5. $\mathrm{P}$ - pričakovanja staršev & 11,47 & 4,19 & $14^{* *}$ &, $39^{* *}$ &, $30^{* *}$ &, $56^{* *}$ & & & & & & & \\
\hline 6. $\mathrm{P}-\mathrm{dvom} \mathrm{v}$ dejanja & 10,31 & 3,18 &, $32^{* *}$ &, $60^{* *}$ &, $36^{* *}$ &, $36^{* *}$ &, $25^{* *}$ & & & & & & \\
\hline 7. $\mathrm{P}-$ organiziranost & 24,71 & 3,84 &,$- 36^{* *}$ &, $11^{* *}$ &, $35^{* *}$ &,$- 09^{*}$ &,- 04 & ,09 & & & & & \\
\hline 8. Depresivnost & 24,81 & 7,15 &, $32^{* *}$ &, $40^{* *}$ & ,08 &, $34^{* *}$ &, $20^{* *}$ &, $39^{* *}$ &,- 06 & & & & \\
\hline 9. D - somatski simptomi & 9,90 & 3,18 & $28^{* *}$ &, $37^{* *}$ &, $14^{* *}$ &, $28^{* *}$ & $23^{* *}$ &, $35^{* *}$ &,- 01 &, $88^{* *}$ & & & \\
\hline 10. D - negativni afekt & 6,52 & 2,57 & $25^{* *}$ &, $38^{* *}$ &, $14^{* *}$ & $29^{* *}$ &, $18^{* *}$ & $36^{* *}$ &,- 03 &, $88^{* *}$ &, $73^{* *}$ & & \\
\hline 11. D - anhedonija & 8,38 & 2,73 &, $27^{* *}$ & $25^{* *}$ &,- 09 & $29^{* *}$ & ,09 &, $27^{* *}$ &,$- 11^{*}$ &, $76^{* *}$ &, $45^{* *}$ &, $50^{* *}$ & \\
\hline 12. Anksioznost & 45,88 & 5,34 & $27^{* *}$ &, $44^{* *}$ &, $11^{*}$ &, $19^{* *}$ &, 12 &, $39^{* *}$ &, $12^{*}$ &, $45^{* *}$ &, $46^{* *}$ &, $47^{* *}$ &, $21^{* *}$ \\
\hline
\end{tabular}

Opombe. $\mathrm{P}$ - perfekcionizem, D - depresivnost. Višji rezultati na lestvicah akademske prokrastinacije, perfekcionizma, depresivnosti in anksioznosti nakazujejo na višjo stopnjo izraženosti posameznih konstruktov.

$N=403$

${ }^{*} p<0,05 ;{ }^{* *} p<0,01$.

\section{Rezultati}

\section{Opisne statistike in korelacije med preučevanimi spremenljivkami}

V tabeli 1 predstavljamo opisne statistike za vse vključene spremenljivke in mere povezanosti med spremenljivkami. Akademsko odlašanje se pozitivno povezuje $\mathrm{z}$ vsemi neprilagojenimi dimenzijami perfekcionizma; zaskrbljenostjo zaradi napak, starševsko kritiko, pričakovanji staršev in dvomom $\mathrm{v}$ dejanja, negativno pa se povezuje $\mathrm{s}$ prilagojenima dimenzijama perfekcionizma osebni standardi ter organiziranost. Akademsko odlašanje se pozitivno povezuje tudiz depresivnostjo in anksioznostjo. Neprilagojene dimenzije perfekcionizma zaskrbljenost zaradi napak, starševska kritika, pričakovanja staršev in dvom v dejanja se pozitivno povezujejo $\mathrm{z}$ depresivnostjo ter anksioznostjo. Pričakujemo lahko, da se pri posameznikih $\mathrm{z}$ močneje izraženimi neprilagojenimi dimenzijami perfekcionizma $\mathrm{v}$ večji meri pojavljajo odlašajoči vzorci vedenja na akademskem področju, simptomi anksioznosti in depresivnosti. Prilagojena dimenzija perfekcionizma osebni standardi se pozitivno povezuje $\mathrm{z}$ anksioznostjo in dvema faktorjema depresivnosti: somatskimi simptomi ter negativnim afektom. Dimenzija organiziranost se pozitivno povezuje le $\mathrm{z}$ anksioznostjo in faktorjem depresivnosti anhedonija. Posamezniki z višjimi vrednostmi na prilagojenih dimenzijah perfekcionizma dosegajo tudi višje vrednosti na lestvici anksioznosti in faktorjih depresivnosti, pri čemer so pozitivne povezave med prilagojenimi oblikami perfekcionizma, anksioznostjo in depresivnostjo znatno nižje kot med neprilagojenimi oblikami perfekcionizma, anksioznostjo in depresivnostjo.

\section{Dimenzije perfekcionizma kot napovedniki akademskega odlašanja in kot moderatorji odnosa med anksioznostjo ter akademskim odlašanjem}

V prvem koraku oblikovanega modela (tabela 2) smo vnesli spol in starost, pri čemer se je le spol izkazal kot pomemben pozitiven napovednik akademskega odlašanja; višja stopnja akademskega odlašanja je značilnejša za moški spol. V modelu 1 spremenljivki spol in starost pojasnita 9,4 $\%$ variance $\mathrm{v}$ spremenljivki akademsko odlašanje. $\mathrm{V}$ drugem koraku smo vnesli spremenljivko anksioznost, ki se je izkazala kot pomemben napovednik akademskega odlašanja. V modelu 2 anksioznost dodatno pojasni približno $8 \%$ variance v spremenljivki akademsko odlašanje. Pri udeležencih, ki dosegajo višje dosežke na lestvici anksioznosti, se akademsko odlašanje pojavlja $\mathrm{v}$ večji meri. $\mathrm{V}$ tretjem koraku smo vnesli vseh šest dimenzij perfekcionizma, pri čemer so vsi napovedniki v modelu 3 pojasnili $38,0 \%$ variance $\mathrm{v}$ spremenljivki akademsko odlašanje. Kot pomembna negativna napovednika akademskega odlašanja sta se izkazali prilagojeni dimenziji osebni standardi in organiziranost, kar nakazuje na to, da se pri udeležencih z močneje izraženimi prilagojenimi dimenzijami perfekcionizma $\mathrm{v}$ manjši meri pojavlja odlašanje $\mathrm{z}$ akademskimi obveznostmi. Od neprilagojenih dimenzij pozitivno napoveduje akademsko odlašanje le dimenzija dvom v dejanja. Udeleženci z močneje izraženo dimenzijo dvom $\mathrm{v}$ dejanja $\mathrm{v}$ večji meri odlašajo $\mathrm{z}$ akademskimi obveznostmi. V četrtem koraku smo vnesli posamezne interakcije med dimenzijami perfekcionizma in anksioznostjo, vendar se je pojasnjena varianca v modelu 4 povišala le za približno $2 \%$. Kot edina statistično značilna interakcija pri napovedovanju akademskega odlašanja se je izkazala interakcija med dimenzijo perfekcionizma osebni standardi in anksioznostjo. V pogoju nizke anksioznosti je učinek višine osebnih standardov na akademsko odlašanje 
Tabela 2. Rezultati hierarhične multiple regresije za napovedovanje akademskega odlašanja na podlagi dimenzij perfekcionizma in anksioznosti

\begin{tabular}{|c|c|c|c|c|c|c|c|c|c|}
\hline & \multicolumn{8}{|c|}{ Akademsko odlašanje } \\
\hline & & \multicolumn{2}{|c|}{ Model 1} & \multicolumn{2}{|c|}{ Model 2} & \multicolumn{2}{|c|}{ Model 3} & \multicolumn{2}{|c|}{ Model 4} \\
\hline & & $B$ & $\beta$ & $B$ & $\beta$ & $B$ & $\beta$ & $B$ & $\beta$ \\
\hline \multirow[t]{3}{*}{ Korak 1: } & Konstanta & 64,90 & & 64,90 & & 64,91 & & 64,50 & \\
\hline & Spol & $-11,36$ &,$- 30^{* * *}$ & $-11,86$ &,$- 32^{* * *}$ & $-8,85$ &,$- 24^{* * *}$ & $-9,30$ &,$- 25^{* * *}$ \\
\hline & Starost & $-0,29$ &,- 04 & $-0,13$ &,- 00 & 0,17 &, 02 & 0,15 &, 02 \\
\hline Korak 2: & Anksioznost & & & 0,92 &, $28^{* * *}$ & 0,73 &, $22^{* * *}$ & 0,66 &, $20^{* * *}$ \\
\hline \multirow[t]{6}{*}{ Korak 3: } & $\begin{array}{l}\mathrm{P} \text { - zaskrbljenost } \\
\text { zaradi napak }\end{array}$ & & & & & $-0,06$ &,- 02 & $-0,07$ &,- 03 \\
\hline & $\begin{array}{l}\mathrm{P}-\text { osebni } \\
\text { standardi }\end{array}$ & & & & & $-0,76$ &,$- 23^{* * *}$ & $-0,78$ &,$- 23^{* * *}$ \\
\hline & $\begin{array}{l}\mathrm{P}-\text { starševska } \\
\text { kritika }\end{array}$ & & & & & 0,04 &, 01 & $-0,04$ &,- 01 \\
\hline & $\begin{array}{l}\mathrm{P} \text { - pričakovanja } \\
\text { staršev }\end{array}$ & & & & & 0,45 &, 11 & 0,49 &, 12 \\
\hline & $\mathrm{P}-$ dvom $\mathrm{v}$ dejanja & & & & & 1,60 &, $29^{* * *}$ & 1,60 &, $29^{* * *}$ \\
\hline & $\mathrm{P}-$ organiziranost & & & & & $-1,29$ &,$- 29^{* * *}$ & $-1,24$ &,$- 28^{* * *}$ \\
\hline \multirow[t]{9}{*}{ Korak 4: } & $\begin{array}{l}\mathrm{P}-\text { zaskrbljenost } \\
\text { zaradi napak } \times \\
\text { anksioznost }\end{array}$ & & & & & & & 0,05 &, 10 \\
\hline & $\begin{array}{l}\mathrm{P}-\text { osebni } \\
\text { standardi } \times \\
\text { anksioznost }\end{array}$ & & & & & & & $-0,08$ &,$- 14^{* * *}$ \\
\hline & $\begin{array}{l}\mathrm{P}-\text { starševska } \\
\text { kritika } \times \\
\text { anksioznost }\end{array}$ & & & & & & & $-0,10$ &,- 09 \\
\hline & $\begin{array}{l}\mathrm{P}-\text { pričakovanja } \\
\text { staršev } \times \\
\text { anksioznost }\end{array}$ & & & & & & & 0,00 &, 01 \\
\hline & $\begin{array}{l}\mathrm{P}-\text { dvom } \mathrm{v} \\
\text { dejanja } \times \\
\text { anksioznost }\end{array}$ & & & & & & & 0,01 &, 01 \\
\hline & $\begin{array}{l}\mathrm{P}-\text { organiziranost } \\
\times \text { anksioznost }\end{array}$ & & & & & & & 0,04 &, 04 \\
\hline & $\Delta R^{2}$ & \multicolumn{2}{|c|}{, $09^{* * *}$} & \multicolumn{2}{|c|}{, $08^{* * *}$} & \multicolumn{2}{|c|}{, $21^{* * *}$} & \multicolumn{2}{|c|}{, $02^{*}$} \\
\hline & $R^{2}$ & \multicolumn{2}{|c|}{, $09^{* * *}$} & \multicolumn{2}{|c|}{, $17^{* * *}$} & \multicolumn{2}{|c|}{, $38^{* * *}$} & \multicolumn{2}{|c|}{, 40} \\
\hline & $F$ za spremembo $R^{2}$ & \multicolumn{2}{|c|}{20,70} & \multicolumn{2}{|c|}{37,76} & \multicolumn{2}{|c|}{21,94} & \multicolumn{2}{|c|}{1,79} \\
\hline
\end{tabular}

Opombe. $\mathrm{P}$ - perfekcionizem.

${ }^{*} p<0,05 ;{ }^{* *} p<0,01 .{ }^{* *} p<0,001$.

zanemarljiv, medtem ko je v pogoju visoke anksioznosti za udeležence $\mathrm{z}$ nizkimi osebnimi standardi statistično značilna višja stopnja odlašanja $\mathrm{z}$ akademskimi obveznostmi (slika 1).

\section{Dimenzije perfekcionizma kot napovedniki akademskega odlašanja in kot moderatorji odnosa med depresivnostjo ter akademskim odlašanjem}

$\mathrm{V}$ nadaljevanju smo oblikovali podoben model, $\mathrm{v}$ katerem smo v drugem koraku namesto anksioznosti vstavili depresivnost (tabela 3). V prvem koraku oblikovanega modela smo vnesli spol in starost, pri čemer se je spol izkazal kot pomemben pozitiven napovednik akademskega odlašanja; višja stopnja akademskega odlašanja je značilnejša za moški spol (spol in starost sta pojasnila 9,4\% variance v dosežkih akademskega odlašanja). Spremenljivka depresivnost, vnesena $\mathrm{v}$ drugem koraku, se je izkazala kot pomemben pozitiven napovednik akademskega odlašanja, pri čemer je $\mathrm{v}$ modelu 2 dodatno pojasnila okoli $10 \%$ variance v spremenljivki akademsko odlašanje. Pri udeležencih, ki dosegajo višje dosežke na lestvici depresivnosti, se akademsko odlašanje pojavlja v večji meri. V tretjem koraku smo vnesli posamezne dimenzije perfekcionizma, pri čemer so napovedniki v modelu 3 pojasnili $37,1 \%$ variance $\mathrm{v}$ spremenljivki akademsko odlašanje, pri čemer so spremenljivke perfekcionizma dodatno pojasnile 17,5 \% variance. Prilagojeni dimenziji osebni standardi in organiziranost napovedujeta pojav akademskega odlašanja $\mathrm{v}$ negativni smeri, kar nakazuje na to, da ob višji stopnji prilagojenih dimenzij perfekcionizma upada pojav odlašanja $\mathrm{Z}$ akademskimi obveznostmi. 
Tabela 3. Rezultati hierarhične multiple regresije za napovedovanje akademskega odlašanja na podlagi dimenzij perfekcionizma in depresivnosti

\begin{tabular}{|c|c|c|c|c|c|c|c|c|c|}
\hline & \multicolumn{8}{|c|}{ Akademsko odlašanje } \\
\hline & & \multicolumn{2}{|c|}{ Model 1} & \multicolumn{2}{|c|}{ Model 2} & \multicolumn{2}{|c|}{ Model 3} & \multicolumn{2}{|c|}{ Model 4} \\
\hline & & $B$ & $\beta$ & $B$ & $\beta$ & $B$ & $\beta$ & $B$ & $\beta$ \\
\hline \multirow[t]{3}{*}{ Korak 1: } & Konstanta & 64,90 & & 64,90 & & 64,91 & & 65,32 & \\
\hline & Spol & $-11,35$ &,$- 30^{* * *}$ & $-11,42$ &,$- 31^{* * *}$ & $-8,83$ &,$- 24^{* * *}$ & $-8,55$ &,$- 23^{* * *}$ \\
\hline & Starost & $-0,29$ &,- 04 & $-0,08$ &,- 01 & 0,17 &, 02 & 0,23 &, 03 \\
\hline Korak 2: & Depresivnost & & & 0,78 &, $32^{* * *}$ & 0,48 &, $20^{* * *}$ & 0,55 &, $23^{* * *}$ \\
\hline \multirow[t]{6}{*}{ Korak 3: } & $\begin{array}{l}\mathrm{P} \text { - zaskrbljenost } \\
\text { zaradi napak }\end{array}$ & & & & & 0,05 &, 02 & $-0,01$ &,- 00 \\
\hline & $\begin{array}{l}\mathrm{P}-\text { osebni } \\
\text { standardi }\end{array}$ & & & & & $-0,81$ &,$- 24^{* * *}$ & $-0,75$ &,$- 22^{* * *}$ \\
\hline & $\mathrm{P}$ - starševska kritika & & & & & $-0,16$ &,- 03 & $-0,22$ &,- 04 \\
\hline & $\begin{array}{l}\mathrm{P} \text { - pričakovanja } \\
\text { staršev }\end{array}$ & & & & & 0,44 &, 11 & 0,51 & ,12 \\
\hline & $\mathrm{P}-$ dvom $\mathrm{v}$ dejanja & & & & & 1,61 &, $30^{* * *}$ & 1,60 &, $29^{* * *}$ \\
\hline & $\mathrm{P}-$ organiziranost & & & & & $-1,13$ &,$- 25^{* * *}$ & $-1,14$ &,$- 25^{* * *}$ \\
\hline \multirow[t]{9}{*}{ Korak 4: } & $\begin{array}{l}\mathrm{P} \text { - zaskrbljenost } \\
\text { zaradi napak } \times \\
\text { depresivnost }\end{array}$ & & & & & & & 0,00 &, 01 \\
\hline & $\begin{array}{l}\mathrm{P}-\text { osebni } \\
\text { standardi } \times \\
\text { depresivnost }\end{array}$ & & & & & & & $-0,03$ &,- 07 \\
\hline & $\begin{array}{l}\mathrm{P} \text { - starševska kritika } \\
\times \\
\text { depresivnost }\end{array}$ & & & & & & & 0,05 &, 07 \\
\hline & $\begin{array}{l}\mathrm{P}-\text { pričakovanja } \\
\text { staršev } \times \\
\text { depresivnost }\end{array}$ & & & & & & & $-0,06$ &,$- 14^{*}$ \\
\hline & $\begin{array}{l}\mathrm{P}-\text { dvom } \mathrm{v} \text { dejanja } \times \\
\text { depresivnost }\end{array}$ & & & & & & & $-0,03$ &,- 04 \\
\hline & $\begin{array}{l}\mathrm{P}-\text { organiziranost } \times \\
\text { depresivnost }\end{array}$ & & & & & & & 0,04 &, 07 \\
\hline & $\Delta R^{2}$ & \multicolumn{2}{|c|}{, $09^{* * *}$} & \multicolumn{2}{|c|}{, $10^{* * *}$} & \multicolumn{2}{|c|}{, $18^{* * *}$} & \multicolumn{2}{|c|}{, $02^{*}$} \\
\hline & $R^{2}$ & \multicolumn{2}{|c|}{, $09^{* * *}$} & \multicolumn{2}{|c|}{, $19^{* * *}$} & \multicolumn{2}{|c|}{, $37^{* * *}$} & \multicolumn{2}{|c|}{, $39^{*}$} \\
\hline & $F$ za spremembo $R^{2}$ & \multicolumn{2}{|c|}{21,11} & \multicolumn{2}{|c|}{50,00} & \multicolumn{2}{|c|}{8,05} & \multicolumn{2}{|c|}{2,61} \\
\hline
\end{tabular}

Opombe. $\mathrm{P}$ - perfekcionizem.

${ }^{*} p<0,05 ;{ }^{* *} p<0,001$.

Nasprotno velja za neprilagojeno dimenzijo dvom v dejanja, ki pozitivno napoveduje akademsko odlašanje. Višja stopnja izraženosti omenjene dimenzije nakazuje na višjo stopnjo zaznanega odlašanja $\mathrm{z}$ akademskimi obveznostmi. V četrtem koraku smo vnesli posamezne interakcije med dimenzijami perfekcionizma in depresivnostjo. Interakcijski napovedniki so dodatno pojasnili le 2,5\% variance $\mathrm{v}$ spremenljivki akademsko odlašanje. Kot statistično pomembna interakcija se je izkazala interakcija med dimenzijo perfekcionizma pričakovanje staršev in depresivnostjo. V pogoju nizke depresivnosti je učinek višine pričakovanj staršev na akademsko odlašanje zanemarljiv, medtem ko je $\mathrm{v}$ pogoju visoke depresivnosti za udeležence $\mathrm{z}$ nizkimi pričakovanji staršev statistično značilna višja stopnja odlašanja $\mathrm{Z}$ akademskimi obveznostmi (slika 2).

\section{Razprava}

Namen prispevka je bil osvetliti in izboljšati prepoznavnost problematike odlašanja na akademskem področju $\mathrm{v}$ slovenskem prostoru. $\mathrm{V}$ raziskavi smo želeli preučiti odnose med akademskim odlašanjem, perfekcionizmom, anksioznostjo in depresivnostjo, predvsem pa ugotoviti, kakšna je vloga perfekcionizma, depresivnosti in anksioznosti kot morebitnih dejavnikov akademskega odlašanja. Natančneje, osrednji cilj je bil preveriti, ali dimenzije perfekcionizma pomembno moderirajo odnos med stopnjo anksioznosti in stopnjo akademskega odlašanja ter stopnjo depresivnosti in stopnjo akademskega odlašanja.

$\mathrm{Na}$ slovenskem vzorcu študentov so se pokazale statistično značilne povezave med vsemi obravnavanimi spremenljivkami, pri čemer so dobljene ugotovitve skladne 


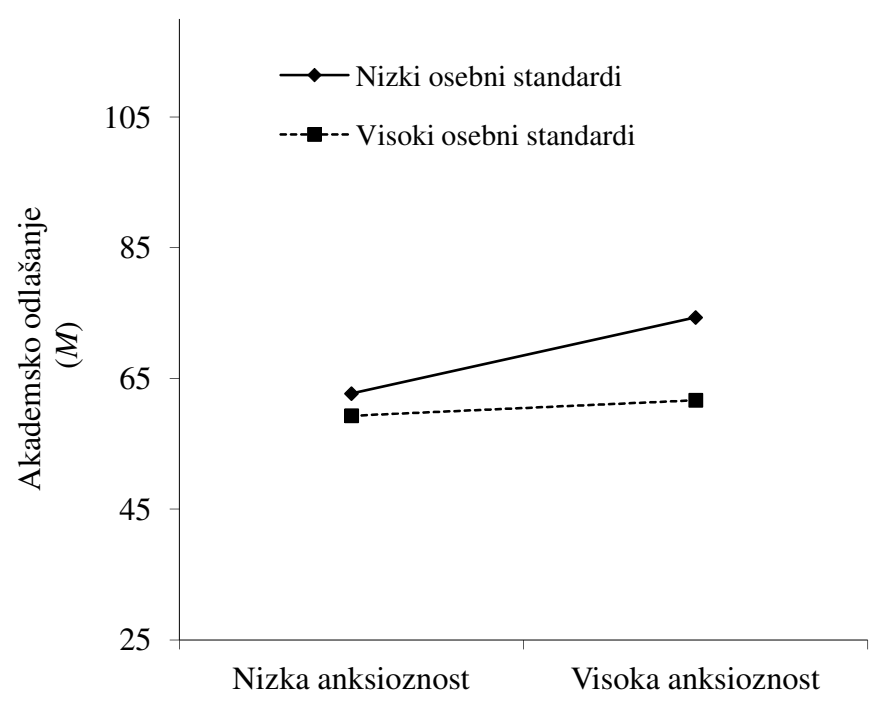

Slika 1. Grafični prikaz dimenzije perfekcionizma osebni standardi kot moderatorja odnosa med stopnjo anksioznosti in akademskim odlašanjem.

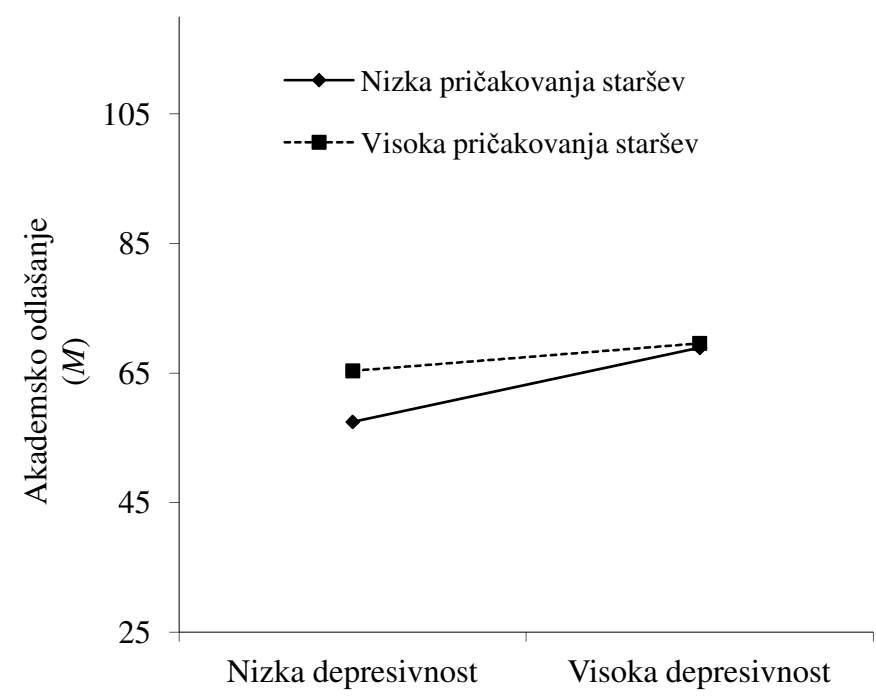

Slika 2. Grafični prikaz dimenzije perfekcionizma pričakovanja staršev kot moderatorja odnosa med stopnjo depresivnosti in akademskim odlašanjem.

z rezultati tako starejših kot novejših raziskav (Burnam idr., 2014; Frost idr., 1990; Jadidi idr., 2011). Pri posameznikih z višje izraženimi neprilagojenimi oblikami perfekcionizma (zaskrbljenost zaradi napak, starševska kritika, pričakovanja staršev in dvom v dejanja) se v večji meri pojavlja odlašanje z akademskimi obveznostmi. Omenjenima konstruktoma so namreč skupni strah pred neuspehom, posameznikovo osredotočanje na doseganje standardov, postavljenih s strani drugih, in kritično ocenjevanje s strani drugih (Onwuegbuzie, 2000). V raziskavi pa nismo preverili le morebitnih povezav med omenjenima konstruktoma, temveč tudi napovedno vrednost neprilagojenih dimenzij perfekcionizma pri napovedovanju akademskega odlašanja. Naši rezultati so pokazali, da akademsko odlašanje napoveduje le ena od štirih neprilagojenih dimenzij perfekcionizma - dimenzija dvom v dejanja. Posamezniki, ki dvomijo v lastne sposobnosti glede dobro opravljenih nalog, bodo $\mathrm{v}$ večji meri odlašali z akademskimi obveznostmi. Omenjena dimenzija predstavlja za posameznika problem (Burnam idr., 2014; Frost idr., 1990;), zaradi česar lahko upravičeno domnevamo, da so takšne povezave nefunkcionalne, saj posameznika neprilagojene perfekcionistične težnje ovirajo pri dokončevanju obveznosti.

Nasprotno sta prilagojeni dimenziji perfekcionizma (osebni standardi in organiziranost) tisti, ki sta od vseh dimenzij najbolj funkcionalni, saj odražata pozitivne vidike perfekcionizma, kot so osebna drža glede organiziranosti, postavitev visokih standardov in posameznikovo stopnjo osebne motivacije pri doseganju različnih dosežkov (Frost idr., 1990). Na slovenskem vzorcu študentov smo potrdili negativno povezanost med prilagojenima dimenzijama perfekcionizma in akademskim odlašanjem, pri čemer smo v naslednjem koraku potrdili tudi obstoj negativnih napovednih vrednosti prilagojenih dimenzij perfekcionizma pri napovedovanju akademskega odlašanja. Omenjeni pozitivni dimenziji perfekcionizma odražata posameznikovo orientiranost k nalogam, ustrezno izvedbo nalog, nizko stopnjo samokritičnosti in boljšo samopodobo (Rice, Leever, Noggle in Lapsley, 2007), kar rezultira v nižji stopnji pojavnosti odlašanja $\mathrm{z}$ akademskimi obveznostmi. Dobljeni rezultati so skladni z ugotovitvami Burnama in sodelavcev (2014). Domnevamo, da ima v tem vidiku pomembno vlogo notranja motivacija, katero izkazujejo posamezniki z višjo stopnjo samodeterminacije, organiziranosti in ciljne usmerjenosti. Zaradi prisotne motivacije pri opravljanju akademskih obveznosti in sposobnosti spretnejšega organiziranja časa posledično ne prihaja do pojava vzorcev odlašanja $\mathrm{z}$ akademskim delom. V nadaljnje raziskovalne modele bi tako bilo smiselno vključiti stopnjo posameznikove notranje in zunanje motivacije.

Tako perfekcionizem kot akademsko odlašanje imata različne neugodne povezave, pri čemer sta posebej izpostavljeni anksioznost in depresivnost. Neprilagojene dimenzije perfekcionizma se tako pogosto pozitivno povezujejo $\mathrm{z}$ depresivnostjo, anksioznostjo in neprilagojenimi strategijami spoprijemanja (Frost idr., 1990; Stoeber in Otto, 2006). Slednje so potrdili tudi naši rezultati, v sklopu katerih bi izpostavili predvsem dimenziji zaskrbljenost zaradi napak in dvom v dejanja, ki se najmočneje povezujeta tako z anksioznostjo kot depresivnostjo. Obe dimenziji izražata splošen strah pred neuspehom, ki ga tvorijo težnje $\mathrm{k}$ negativnemu reagiranju na napake, pričakovanju neodobravanja in dvomov v lastne sposobnosti. Slednje povzroča posamezniku psihološki distres, ga ovira in nadalje vodi k pasivnemu ter izogibalnemu vedenju.

V okviru preučevanja akademskega odlašanja Flett idr. (1995) poročajo o močnejših pozitivnih povezavah med akademskim odlašanjem in depresivnostjo $\mathrm{v}$ primerjavi $\mathrm{s}$ povezavo med akademskim odlašanjem ter anksioznostjo. S temi ugotovitvami so skladni tudi naši rezultati, saj je na našem vzorcu udeležencev pozitivna povezanost med akademskim odlašanjem in depresivnostjo statistično značilno višja kot povezanost med akademskim odlašanjem ter anksioznostjo. Simptomi depresivnosti in pridružene 
tesnobe izhajajo iz pojava negativnih avtomatskih misli (tj. kognitivna komponenta depresije; Flett idr., 1995) ter strahu pred neuspehom (Solomon in Rothblum, 1984), pri čemer negativne misli, pesimizem ali občutek brezupnosti vodijo $\mathrm{v}$ izogibalno oziroma umikajoče vedenje (Beck, Rush, Shaw in Emery, 1979; Flett idr., 1995). Takšno vedenje avtorji enačijo z vedenjem samooviranja - posamezniki z močneje izraženimi negativnimi prepričanji o lastni kognitivni učinkovitosti pogosteje dvomijo v svoje sposobnosti za ustrezno opravljanje nalog, kar pomembno vpliva tako na stopnjo posameznikove motivacije kot na njihov začetek opravljanja obveznosti in vztrajanja pri njih (Spada idr., 2006). Čeprav v našo raziskavo nismo vključili spremenljivke samooviranja, lahko slednje pripomore $\mathrm{k}$ pojasnjevanju ozadja pozitivne povezave med akademskim odlašanjem in depresivnostjo. Predlagamo, da prihodnje raziskave akademskega odlašanja $\mathrm{v}$ svoje raziskovalne načrte vključijo tudi posameznikovo stopnjo nagnjenosti $\mathrm{k}$ samooviralnemu vedenju.

V sklopu preučevanja odnosov med akademskim odlašanjem, anksioznostjo in depresivnostjo je potrebno natančno opredeliti naravo njihovih odnosov. $\mathrm{V}$ raziskavi smo predpostavili, da anksioznost in depresivnost pomembno ter pozitivno napovedujeta akademsko odlašanje. Rezultati na našem vzorcu so to predvidevanje potrdili. Dobljene ugotovitve so skladne $\mathrm{z}$ ugotovitvami Changa (2014): študentje, ki izražajo višjo stopnjo anksioznosti v večji meri odlašajo z akademskim delom in obveznostmi. V tem primeru se akademsko odlašanje lahko obravnava kot strategija spoprijemanja, še posebej v šolskem okolju, kjer je prisotno veliko dela pod časovnim pritiskom (Choi in Moran, 2009).

Da bi odgovorili na naše osrednje raziskovalno vprašanje, smo s pomočjo dveh oblikovanih modelov preverili, v kolikšni meri posamezne dimenzije perfekcionizma moderirajo odnos med stopnjo anksioznosti in depresivnosti ter akademskim odlašanjem. Oba ugotovljena interakcijska učinka sta majhna; na slovenskem vzorcu študentov odnos med stopnjo anksioznosti in akademskim odlašanjem moderira le prilagojena dimenzija perfekcionizma osebni standardi, medtem ko odnos med stopnjo depresivnosti in akademskim odlašanjem moderira dimenzija pričakovanje staršev. Pri posameznikih $\mathrm{z}$ višjo stopnjo izraženosti dimenzije osebni standardi se bodo vzorci odlašanja $z$ akademskimi obveznostmi pojavljali v manjši meri, tudi pod pogojem prisotne anksioznosti. Takšni rezultati so skladni z ugotovitvami Changa (2014); mehanizem, ki botruje omenjenemu izidu pa bi domnevno naj bila posameznikova notranja motivacija. Zaradi tega so implikacije teh ugotovitev dobrodošle predvsem $\mathrm{v}$ šolskem kontekstu in so vezane na spodbujanje notranje motivacije ter sledenje učnim programom storilnostne motivacije. V sklopu slednjih je za posameznike predvsem pomembna optimalna zahtevnost nalog; če so naloge preveč zahtevne lahko posameznik razvije strah pred neuspehom, kar vzdržuje tako anksioznost kot odlašanje $\mathrm{z}$ akademskim delom. Ker se akademsko odlašanje pojmuje tudi kot neprilagojena strategija spoprijemanja $\mathrm{z}$ anksioznostjo, skladno s predlogi Changa priporočamo, da se v šolskem kontekstu uporabljajo tehnike za zmanjševanje anksioznosti (npr. dihalne vaje, psihoedukacija in kognitivno restrukturiranje).
Nadalje je raziskava pokazala, da odnos med stopnjo depresivnosti in akademskim odlašanjem moderira neprilagojena dimenzija pričakovanja staršev, je pa bil interakcijski učinek majhen. Posamezniki, ki dosegajo nižje vrednosti na neprilagojeni dimenziji pričakovanja staršev, ocenjujejo, da starši do njih nimajo velikih pričakovanj, kar verjetno minimalizira njihov trud pri opravljanju šolskih obveznosti in doseganju dobrih rezultatov. Za posameznike, ki izražajo višjo stopnjo depresivne simptomatike, bo torej odlašanje $\mathrm{z}$ akademskim delom pogostejše, še posebej $\mathrm{v}$ pogoju, kadar posameznik ocenjuje, da so pričakovanja njegovih staršev zanj nizka. $\mathrm{V}$ tem delu raziskave so rezultati delno potrdili naša predvidevanja. Ker se pričakovanja $\mathrm{v}$ tem vidiku niso $\mathrm{v}$ celoti izpolnila (nobena od ostalih neprilagojenih dimenzij pomembno ne moderira odnosa med stopnjo depresivnosti in stopnjo akademskega odlašanja), domnevamo, da imajo v tem vidiku dimenzije perfekcionizma mediatorsko vlogo.

V zadnjem delu poglavja želimo izpostaviti tudi pomembno napovedno vrednost spola pri napovedovanju dosežkov na lestvici akademskega odlašanja. V naši raziskavi se je izkazalo, da spol pomembno napoveduje stopnjo odlašanja z akademskimi obveznostmi; moški dosegajo višje povprečne vrednosti na lestvici akademskega odlašanja $\mathrm{v}$ primerjavi z ženskami. Takšni rezultati so delno skladni z rezultati raziskave, ki je preverjala razlike med spoloma $\mathrm{v}$ stopnji akademskega odlašanja. Ozer, Demir in Ferrari (2009) so poročali o statistično značilno višji stopnji akademskega odlašanja pri moških, ki tovrstno vedenje uporabljajo zaradi strahu pred neuspehom in lenobe, $\mathrm{z}$ njim tvegajo ter se upirajo nadzoru s strani samega sebe ali drugih.

Obenem je potrebno opozoriti na določene omejitve raziskave, ki jih je potrebno upoštevati pri interpretiranju in posploševanju ugotovitev. Za pridobitev kakovostnih podatkov in ustrezno ločevanje med prilagojenimi in neprilagojenimi oblikami perfekcionizma, bi bilo $\mathrm{v}$ nadaljnjih raziskavah smiselno uporabiti tudi Hewittovo in Flettovo (1991) večdimenzionalno lestvico perfekcionizma, saj bi sočasna uporaba obeh lestvic bistveno pripomogla $\mathrm{k}$ razumevanju akademskega odlašanja. Naslednja omejitev se nanaša na uporabljene samoocenjevalne pripomočke; pri samoocenjevalnih vprašalnikih so namreč odgovori udeležencev lahko izkrivljeni zaradi različnih kognitivnih napak in nagnjenosti $\mathrm{k}$ podajanju socialno zaželenih odgovorov. Ugotovljene povezanosti med spremenljivkami lahko delno pripišemo tudi pristranskosti zaradi uporabe skupne metode ocenjevanja. Prav tako je potrebno opozoriti, da anksioznost in depresivnost, kot smo ju operacionalizirali v pričujoči raziskavi, ne predstavljata kliničnih pojavov. Dodatno omejitev predstavlja tudi priložnostni vzorec udeležencev.

Ocenjujemo, da ima pričujoča raziskava tako teoretične kot praktične implikacije. V prispevku smo podrobno pregledali področje akademskega odlašanja in prikazali nekaj dejavnikov, ki se povezujejo $\mathrm{z}$ obravnavanim konstruktom. Kljub nekaterim omejitvam izvedena raziskava zagotovo prispeva $\mathrm{k}$ celovitemu razumevanju akademskega odlašanja na slovenskem vzorcu študentov; praktične implikacije so zato dobrodošle predvsem v izobraževalnem 
kontekstu. Ustrezna identifikacija in nadomeščanje neprilagojenih perfekcionističnih teženj lahko pomembno doprineseta k manjši stopnji anksioznosti, depresivnosti ter akademskega odlašanja. Posameznike z močneje izraženimi perfekcionističnimi težnjami bi bilo smiselno ponovno seznaniti z ustreznimi delovnimi normami in pričakovanji, z namenom doseganja optimalnih rezultatov ter nižanja stopnje pojavnosti odlašajočega vedenja. $\mathrm{K}$ temu deloma prispeva tudi učitelj (Brophy, 1999); učenca je tako smiselno že na začetku izobraževalne poti voditi k postavljanju realnih predstav in kriterijev o sebi ter nalogah, kar posledično niža tako stopnjo anksioznosti kot odlašanje z akademskim delom. Nadalje Brophy (1999) opozarja tudi na pomen učiteljevega opazovanja šolskih navad učenca in njune medsebojne komunikacije, še posebej pa na učiteljevo podporno vlogo pri krepitvi učenčeve pozitivne storilnostne motivacije, $\mathrm{s}$ čimer niža stopnjo pojavnosti nerealističnih ciljev. V okviru obravnave akademskega odlašanja je smiselno zastaviti preventivne ali intervencijske programe, s katerimi ciljamo na posameznikove organizacijske sposobnosti in strategije spoprijemanja. Kot je bilo omenjeno, $\mathrm{k}$ akademskemu odlašanju prispevajo nizka stopnja motivacije, neustrezna samoregulacija in šibka samodisciplina (Yesil, 2012). Pomembno je, da posameznikom $\mathrm{z}$ visoko stopnjo akademskega odlašanja pomagamo pri krepitvi prej naštetih motivacijskih in psiholoških virov; $\mathrm{z}$ nalaganjem določenih odgovornosti, ustvarjanjem ter prikazom pozitivnih primerov, učenjem spoprijemanja s stresom in anksioznostjo ter ustreznimi povratnimi informacijami. Podpora učencu pri razvijanju ustreznih in celovitih učnih strategij, predstav o sebi ter šolskih obveznosti tako igra pomembno vlogo pri zmanjševanju odlašajočega vedenja ter doseganju konkretnih in realnih ciljev. Rezultati naše raziskave nakazujejo, da tovrstno pomoč in podporo potrebujejo tudi študenti, kar nakazuje na potrebo po psihološkem svetovanju za študente, ki bi bilo usmerjeno $\mathrm{v}$ doseganje večje učinkovitosti pri študiju.

\section{Literatura}

Aiken, L. S. in West, S. G. (1991). Multiple regression: Testing and interpreting interactions. Newbury Park, CA, ZDA: Sage.

Antony, M. in Swinson, R. (2009). When perfect isn't good enough: Strategies for coping with perfectionism. Oakland, CA, ZDA: New Harbinger Publications.

Beck, A. T., Rush, A. J., Shaw, B. F. in Emery, G. (1979). Cognitive therapy of depression. New York, NY, ZDA: The Guilford Press.

Brophy, J. (1996). Working with perfectionist students. Pridobljeno s strani http://www.ericdigests.org/1997-2/ students.htm

Burka, B. J. in Yuen, L. M. (2008). Procrastination: why you do it, what to do about it now (2. izd.). Boston, MA, ZDA: Da Capo Press.

Burnam, A., Komarraju, M., Hamel, R. in Nadler D. R. (2014). Do adaptive perfectionism and self-determined motivation reduce academic procrastination? Learning and Individual Differences, 36, 165-172.
Carleton, R. N., Thibodeau, M. A., Teale, M. J. N., Welch, P. G., Abrams, M. P., Robinson, T. in Asmundson, G. J. G. (2013). The Center for Epidemiologic Studies Depression Scale: A review with a theoretical and empirical examination of item content and factor structure. Plos One, 8, 11-11.

Chang, H. K. (2012). The relationship between perfectionism, anxiety, and academic procrastination in college students. Psychology Student Research Journal, 2, 6-13.

Chang, H. K. (2014). Perfectionism, anxiety, and academic procrastination: The role of intrinsic and extrinsic motivation in college students (magistrsko delo). Pridobljeno s strani http://scholarworks.lib.csusb.edu/ cgi/viewcontent.cgi?article $=1023 \&$ context $=$ etd

Choi, N. J. in Moran, S. V. (2009). Why not procrastinate? Developmentand validation of a new active procrastination scale. The Journal of Social Psychology, 149, 195-211.

Chu, A. H. C. in Choi, J. N. (2005). Rethinking procrastination: Positive effects of "active" procrastination behavior on attitudes and performance. The Journal of Social Psychology, 145, 245-264.

Erozkan, A., Karakas, Y., Ata, S. in Ayberk, A. (2011). The relationship between perfectionism and depression in Turkish high school students. Social Behavior and Personality, 39, 451-464.

Ferrari, J. R. (1992). Procrastinators and perfect behavior: An exploratory factor analysis of self-presentation, selfawareness, and self-handicapping components. Journal of Research in Personality, 26, 75-84.

Flett, G. L., Blankstein, K. R., Hewitt, P. L. in Koledin, S. (1992). Components of perfectionism and procrastination in college students. Social Behavior and Personality, 20, 85-94.

Flett, G. L., Blankstein, K. R. in Martin, T. R. (1995). Procrastination, negative self-evaluation, and stress in depression and anxiety. V Ferrari, J. R., Johnson, J. L. in McCown, W. G. (ur.), Procrastination and task avoidance: Theory, research, and treatment (str.137167). New York, NY, ZDA: Springer.

Flett, G. L in Hewitt, P. L. (2002). Perfectionism and maladjustment: An overview of theoretical, definitional, and treatment issues. V Flett, G. L in Hewitt, P. L. (ur.), Perfectionism: Theory, research and treatment (str. 5-31). Washington, DC, ZDA: American Psychological Association.

Frost, R. O., Heimberg, R. G., Holt, C. S., Mattia, J. I. in Neubauer, A. L. (1993). A comparison of two measures of perfectionism. Personality and Individual Differences, 14, 119-126.

Frost, R. O., Marten, P., Lahart, C. in Rosenblate, R. (1990). The dimensions of perfectionism. Cognitive Therapy and Research, 14, 449-468.

Ganske, K. H. in Ashby, J. S. (2007). Perfectionism and career decision-making self-efficacy. Journal of Employment Counseling, 44, 17-28.

Haycock, L. A., McCarthy, P. in Skay, C. L. (1998). Procrastination in college students: The role of selfefficacy and anxiety. Journal of Counseling \& Development, 76, 317-324. 
Hewitt, P. L. in Flett, G. L. (1991). Perfectionism in the self and social contexts: Conceptualization, assessment, and association with psychopathology. Journal of Personality and Social Psychology, 60, 456-470.

Hollender, M. H. (1965). Perfectionism. Comprehensive Psychiatry, 6, 94-103.

Jadidi, F., Mohammadkhani, S. in Tajrishi, K. Z. (2011). Perfectionism and academic procrastination. Procedia - Social and Behavioral Sciences, 30, 534-537.

Kawamura, K. Y., Hunt, S. L., Frost, R. O. in Marten DiBartolo, P. (2001). Perfectionism, anxiety and depression: Are the relationships independent? Cognitive Therapy and Research, 25, 291-301.

Lamovec, T. (1988). Priročnik za Psihologijo motivacije in emocij [Manual for Psychology of Motivation and Emotion]. Ljubljana, Slovenija: Filozofska fakulteta, Oddelek za psihologijo.

McCloskey, J. D. (2011). Finally, my thesis on academic procrastination (magistrsko delo, University of Texas at Arlington, ZDA). Pridobljeno s strani https://uta-ir.tdl. org/uta-ir/handle/10106/9538

Musek, J. in Avsec, A. (2006). Osebnost, samopodoba in psihično zdravje [Personality, self-concept, and psychological health]. Anthropos, 1-2, 51-75.

Muthén, L. K. in Muthén, B. O. (1998-2010). Mplus user's guide (6. izd.). Los Angeles, CA, ZDA: Muthén \& Muthén.

Onwuegbuzie, A. J. (2000). Academic procrastinators and perfectionistic tendencies among graduate students. Journal of Social Behavior and Personality, 15, 103-110.

Ozer, B. U., Demir, A. in Ferrari, J. R. (2009). Exploring academic procrastination among Turkish students: Possible gender differences in prevalence and reasons. The Journal of Social Psychology, 149, 241-257.

Rice, K. G., Leever, B. A., Noggle, C. A. in Lapsley, D. K. (2007). Perfectionism and depressive symptoms in early adolescence. Psychology in the Schools, 44, 139-156.

Saddler, C. D. in Buley, J. (1999). Predictors of academic procrastination in college students. Psychological Reports, 84, 686-688.
Saddler, C. D. in Sacks L. A. (1993). Multidimensional perfectionism and academic procrastination: Relationship with depression in university students. Psychological Reports, 73, 863-871.

Sever, S., Senegačnik, A. in Vajngerl, K. (2015). Lestvica akademske prokrastinacije - SI [Academic Procrastination Scale - SI]. Neobjavljena seminarska naloga, Oddelek za psihologijo, Filozofska fakulteta, Univerza v Ljubljani, Slovenija.

Schouwenburg, H. C. (1995). Academic procrastination: Theoretical notions, measurement, and research. V Ferrari, J. R., Johnson, J. L. in McCown, W. G. (ur.), Procrastination and task avoidance: Theory, research, and treatment (str. 71-96). New York, NY, ZDA: Springer.

Schraw, G., Wadkins, T. in Olafson, L. (2007). Doing the things we do: A grounded theory of academic procrastination. Journal of Educational Psychology, 99, 12-25.

Slade, P. D. in Owens, R. G. (1998). A dual process model of perfectionism based on reinforcement theory. Behavior Modification, 22, 372-390.

Solomon, L. J. in Rothblum, E. D. (1984). Academic procrastination: Frequency and cognitive-behavioral correlates. Journal of Counseling Psychology, 31, 503-509.

Spada, M. M., Hiou, K. in Nikcevic, A. V. (2006). Metacognitions, emotions, and procrastination. Journal of Cognitive Psychotherapy, 20, 319-326.

Steel, P. (2007). The nature of procrastination: A metaanalytic and theoretical review of quintessential selfregulatory failure. Psychological Bulletin, 133, 65-94.

Stoeber, J. in Otto, K. (2006). Positive conceptions of perfectionism: Approaches, evidence, challenges. Personality and Social Psychology Review, 10, 295-319.

Yesil, R. (2012). Solution for the problem of academic procrastination according to prospective teachers. Educational Research and Reviews, 7, 372-383.

Zhang, B in Cai, T. (2012). Moderating effects of self-efficacy in the relations of perfectionism and depression. Studia Psychologica, 54, 15-21. 